\title{
The Auld Enemy? Exploring the England vs. Scotland rivalry from the perspective of soccer fans
}

\begin{abstract}
A longstanding and persistent rivalry is said to exist between England and Scotland in the context of international soccer. In this essay we seek to test common media representations emphasising division against the opinions of English and Scottish soccer fans themselves. The complexity of English views towards Scottish people both inside and outside of soccer is explored using examples from an online participant observation study with English fans. Moreover, the extent to which anti-English sentiment constitutes an element of Scottish national identity in soccer and society more broadly is also explored using examples from semistructured interviews with Scottish fans on the topic of the rivalry between the two nations. We argue that via representations in the media soccer has both provided the context for reinforcing broader divisions between these neighbouring nations as well as creating specific memories in the minds of soccer fans that enhance divisive feelings amongst some English and Scottish fans. However, we also note the extent to which the stereotype of division is perpetuated by the media and how this is sometimes at odds with the views of both Scottish and English fans alike. We conclude that so long as the media perpetuate division between the two nations in a simplistic manner the reality of the complex and evolving relationship between Scottish and English fans will remain unclear and misunderstood.
\end{abstract}

\section{Introduction}

Academic studies which have explored the relationship between Scottish national identity and sport have frequently highlighted the sporting rivalry between Scotland and England as a topic 
of analytical interest. ${ }^{1}$ The rivalry between the two nations is of particular interest given the unique status offered to the 'home nations' which constitute the representative teams of England, Scotland, Wales and Northern Ireland within the United Kingdom of Great Britain and Northern Ireland (UK), given that they represent the only examples of internationallyrecognised representative teams in sports such as soccer and rugby whilst failing to possess congruent independent statehood or political sovereignty. This privileged status therefore acts to reinforce the distinctiveness of Scottish national identity, with sport replicating other elements of Scottish civic society which maintained independent status within the UK, such as the 'holy trinity' constituted of the Scottish educational, legal and church systems. ${ }^{2}$ Furthermore, given that the first ever international fixture in soccer took place between Scotland and England in 1872, the long history of the rivalry between the 'Auld Enemy' has ensure that the fixture has retained a special status for fans of both teams.

For Scottish national team fans in particular, England have been argued to act as the 'significant other' in comparative terms within the domain of soccer. ${ }^{3}$ However, the gradual decline of the Scottish national team has reduced the frequency of Scottish successes over England, denying Scots the opportunity to demonstrate their ability to compete successfully with their larger neighbours, as was the case historically. This imbalance between the two nations in the sporting domain has also been argued to be analogous to the relationship between Scotland and England in a wider political and economic sense, given the relative population sizes and the political economy within the UK with regards to the distribution of wealth, resources and political power. ${ }^{4}$ However, the salience of the rivalry between the two nations has arguably declined in recent decades, with Scots tending to place a greater emphasis on the importance of the rivalry than their English counterparts, resulting in a degree of disillusionment for Scots due to this lack of reciprocation. ${ }^{5}$ Nonetheless, England still retain the status of main rivals for Scots, even 
if English soccer fans may look elsewhere to opponents such as Germany or Argentina for their main international rivals. ${ }^{6}$

The rivalry between Scotland and England in soccer has also been argued to have manifest itself in a different way, with the behaviour of the 'Tartan Army' of fans of the Scottish international team frequently juxtaposed against that of their English counterparts. In recent decades, the Tartan Army have developed a reputation for good-natured support despite the frequent failures of the Scottish team on the pitch; indeed, the Tartan Army have often been identified as a source of pride for Scots in football. ${ }^{7}$ For Bairner, the Tartan Army also provide an additional opportunity to distinguish Scottish supporters from their English rivals, given that the latter developed an association with the 'English disease' of football hooliganism in the 1980s. ${ }^{8}$ The positive reputation of Scottish football fans has been argued to have led to a degree of self-caricature to reinforce this sense of superiority over England off the field, ${ }^{9}$ despite the fact such attempts should be undermined by the numerous historical examples of drunken, violent or anti-social behaviour by Scottish fans in the 1960s and 1970s. ${ }^{10}$ However, the gradual rehabilitation of the reputation of English national team supporters has negated the possibility for Scots to claim the moral victory off the pitch and is likely to be diminished in the future, ${ }^{11}$ echoing the declining likelihood of a Scottish victory on the pitch. ${ }^{12}$

A final feature of analytical interest regarding the rivalry between Scotland and England is the expression of anti-English sentiment by Scottish soccer fans. The expression of such sentiment has been argued to manifest itself in various ways in both sporting and wider social contexts, ranging from comical remarks (whether benign or deliberately provocative) to more violent and abusive actions. ${ }^{13}$ It can therefore be argued that the existence of anti-Englishness within the attitudes of certain Scots is one of the more adverse features which emerges from the rivalry 
between the two nations, with sport representing the domain in which this sentiment is most frequently expressed. ${ }^{14}$ Moorhouse's extensive work on anti-English sentiment in sport particularly identifies the dependent relationship between Scotland and England as the primary cause of this ill-feeling, resulting in a sense of inferiority which manifests itself in a 'repressed nationalism' for Scots in sport. ${ }^{15}$ For Moorhouse, the annual 'Home Internationals' soccer fixture between Scotland and England acted as a focal point for the expression of anti-English sentiment, with the regular fixtures often associated with historical symbolism of the rivalry between the nations through references to past battles and political ill-feeling. ${ }^{16}$ Whilst the end of the Home Internationals tournament has negated the possibility for regular competitive fixtures between Scotland and England in recent decades, the expression of anti-English sentiment remains salient in media representations of this sporting rivalry, particularly when England are participating at major international tournaments in Scotland's absence. ${ }^{17}$ Media depictions of Scotland versus England internationals have often sensationalised the fixture as being a 'fierce football rivalry' ${ }^{18}$ However, there is little research into the views of English and Scottish soccer fans themselves regarding the rivalry. Elias argued for the sociologist to be a "destroyer of myths", ${ }^{19}$ and so the goal of the current study was to attempt to discover the extent to which the rivalry has been created as a social 'myth' by the British media in the minds of Scottish and English soccer fans.

\section{Methods}

The goal of the current research was to attempt to begin to address this using empirical data collected in two separate studies. The first project was an online participant observation study conducted over a period of fifteen months between 2008 and 2009. The online fan community within which this ethnographic research was based was chosen specifically because of its independence from any single club, governing body or association and is an independent 
website created, maintained and for the use of football fans from all over the globe. The site was established in 2007 and remains active with well over 1,000 members, a figure that continues to grow. In total, 93 members of the online community contributed to the 29 discussion threads that were used as data in the study. ${ }^{20}$ Whilst most of the sample was English $(62 \%)$ and it was their comments that provided the vast majority of the data, fans of other nationalities, including Scottish fans, also contributed with some comments that were utilised as comparative data. The majority of this figuration of fans were male $(92 \%)$ and the age range was large (18-69 years; mean age $=30$ years). Extracts from the study specifically relating to the England-Scotland rivalry are presented in the discussion section below. Findings from two separate discussion threads involving eleven members (all male; nine English and one Scot) of the online community are presented here. Each respondent has been given a number to protect their anonymity.

The second research project took place in 2011, with data generated through 13 semi-structured interviews with Scots who resided in England. Initial contact was made with five personal acquaintances in various geographic locations in south east England and the East Midlands known to meet the above criteria. Thereafter, a theoretical snowball sampling strategy was used, with 8 further participants recruited through personal and professional acquaintances of the original five participants. The interviews ranged in length from 35 to 135 minutes, and the interview data was recorded and fully transcribed verbatim. Each respondent has been given a pseudonym to protect their anonymity.

\section{Discussion}

\section{Online participant observation study}


The study of online interactions between football fans revealed that views of English fans towards Scottish people both within and outside of football varied significantly. It was interesting to note how football fans who interacted within the online forum were keen fans of other sports too an often discussed issues arising from various non-football related competitions/events. One such event was the Wimbledon tennis championships which occurs annually in late June to early July after the English and Scottish domestic football seasons have ended in May. In the summer of 2008 the Scottish player Andy Murray carried Britain's hopes for a Wimbledon Grand Slam and fans on the forum discussed their thoughts on him.

30: $\mathrm{F}^{* *} \mathrm{k}$ Murray, during the last World Cup all he did was slag off England, saying he hopes we get battered every match, then turns 'round and expects to get a lot of support during Wimbledon. (Male, English, Manchester United FC, aged 51)

9: (good posting emoticon) I agree, screw the little jock. (Male, English, Birmingham City FC, aged 24)

8: He strikes me as someone who doesn't really care how much support he gets. If you asked an Englishman if they wanted Scotland to win the World Cup would you expect them to say "Yes"? He's Scottish, there's a rivalry there.... Britain and the $\mathrm{BBC}$ need him more than he needs them.

(Male, English, Manchester United FC, aged 29)

19: In 2006 when Murray said: "I'll be supporting anyone but England" he was blasted by the press but he has since admitted that it was just a joke. But I don't 
care about all that, it's tennis at the end of the day not football. (Male, English, Arsenal FC, aged 21)

Many English fans were supporting Murray as he advanced through the tournament. When he was winning these English fans were all too happy to refer to him as 'British' but there was still an underlying resentment towards him. The researcher asked:

1: Why are so many people on here anti-Murray?

Which sparked further debate relating to the England-Scotland rivalry.

12: Think it goes back to when he said he would like to see England get beat; not only that he's a jock (smiley face emoticon). (Male, English, Tottenham Hotspur FC, aged 49)

19: He said he was joking about that. I think the main problem is the Scottish thing (smiley face emoticon). I don't care about that though. Only reason I'm unsure about him is because he acts like a moody teenager a lot of the time, and he's 21 . Anyway, Murray and Nadal will be coming out in a minute. Who will win? (Pictures of both athletes flexing their muscles).

1: How did you feel about Henman then? Did you get behind him more because he's English? 
In response to this, English fans views were mixed. Some were pro-Henman based upon him being English and thus being more representative of them.

19: I guess I did like Henman more because of the nationality thing, but I still follow Murray's progress quite a lot. In boxing I follow Joe Calzaghe and want him to do well, but I find I'm not as behind him as I would be Ricky Hatton.

Whereas others were anti-Henman because of his middle-class upbringing and Southern English accent. For some the strong North-South divide within English society emphasised by Russell seemed more important than the supposed national rivalry between Scotland and England. $^{21}$

14: I'm English. But saying that, I'd relate to someone from Wales or Scotland more than some posh, fancy well to do nob from London or Brighton. (Male, English, Notts County FC, aged 22)

Perhaps the clearest example of anti-Scottishness from an English fan was the following.

9: I do. I hate Murray. He deserves no respect or support whatsoever. The main reason for this: he is from THE single most racist country on the planet: Scotland. No Scot would ever support an Englishman in anything at all so why the hell should we offer our support to a nation or any member of that nation who hate our guts? Glad he got smashed by a decent player. 
This was a minority view amongst the other English fans in this sample and was quickly contested by a Scottish fan, resulting in the following antagonistic exchange.

46: The single most racist country on the planet, you really are a **** aren't you? In what wat does not wanting your traditional rivals to win (even if you don't consider that to be Scotland anymore) equal racism, oh and by the wat when did English become a race? I never want England (same as I don't really care about Wales and Northern Ireland unless of course they play England) to do well in SPORT and that's the key thing SPORT but I certainly do not hate English people and neither do most Scots. I take it you will stop supporting Birmingham given that they have apparently got a racist manager, assistant manager, coach and two of your players mist be racist as well Gary O'Conner and James McFadden because they all come from Scotland and apparently are racist by your definition. Finally, I don’t particularly care that you didn’t support Andy Murray because he was Scottish (hang on doesn't that make you as racist as us apparently), your comment was a disgrace and certainly an exaggeration. (Male, Scottish, Greenock Morton FC, aged 27)

9: Okay firstly, the reason I don't support Andy Murray is NOT because he's Scottish alone. It's because of his attitude of unjustifiable hatred towards the English for no apparent reason. He has publically slated the English and then expects them to support him. I also think he's a moody, arrogant little ******, but that has nothing to do with his nationality. Although, I do feel that his attitude is not uncommon among Scots, they are a nation with a chip on their shoulder and, in my experience, they hate the English on more than a sporting level. I do realise 
that I am generalising a nation's attitudes and that's wrong. However, I do feel that Murray fits into this category, whether it be a minority of majority. I realise that my comments were rash and that they may have offended you, I apologise for that. I was simply relaying my reasons for disliking Murray and attempting to explain why he is such a dislikeable character. I realise that not all Scottish people are as I termed 'racist' I was simply implying that there is a culture of negativity towards the English on all levels in Scotland, and you cannot deny that. And FYI I'm not a huge fan of McCleish because I'm unsure about his managerial skills (not his nationality).

46: He is an arrogant, moody $* * * * * *$ I agree with you there but I have never read or seen him say that he hates England or English people, if you basing that on his comment "anyone but England" he made a joke about the World Cup not about English people in general. I would think if he actually said that he hated England then people like Tim Henman would not talk about him in ways that suggest they are friends. Again I think we have to agree to disagree I do not believe that there is an attitude of hating the English. I am not saying that there isn't a minority who do hate the English, but for the majority there is a good relationship with our neighbours south of the border which is only threatened by a media that wants to cause trouble, people like Kelvin MacKenzie (I know Scottish name but he's not) anti-Scottish rants in the Sun. Is it any wonder there is a lot of people who want independence when you have idiots like that in the English media (his column is not in the Scottish Sun for obvious reasons)...there may be a minority but I certainly don't see a culture of negativity towards the English. I personally feel 
there is a growing negativity the other way around this is possibly due to devolution and the fact Scottish MPs still vote on English only matters.

9: Okay well as you said, we'll have to agree to disagree. I am sort if I offended or upset you that was not my intention.

In a separate discussion thread on the Beijing 2008 Olympics there was also much debate about the England-Scotland rivalry. The researcher began the thread with the following questions.

1: Do you feel more British when the Olympics is on? Do the Olympics bring the English, Scots, Welsh and Northern Irish together?

The responses to these questions highlighted how many English fans believed the media hype regarding an England-Scotland rivalry both inside and outside sport demonstrating a familiar ‘little Englander’ mentality.

17: I'm about an hour from Scotland and don't consider myself to have anything in common with them. I'm closer to Edinburgh than London but I consider myself English. (Male, English, Arsenal FC, aged 20)

However, others were keen to stress that it is only really a sporting rivalry and that the nations within the UK are all interrelated in a variety of ways anyway.

47: I'd say overall most people are happy to be part of the UK, it's actually only really in sport where there is any division. When our troops go to war, they are 
British, and we honour each of them equally whether they are English or Welsh or Scottish. When our country interacts with the world it is as the UK, not as individual entities. I don't see Scotland or Wales as home to be fair - but then I don't see the North of England or the Midlands as my home, to me they are all regions of one country, each with slightly different histories and traditions. When I'm in Bristol for example the city is far more connected to Wales than it is to Newcastle, the links have been there for centuries, since the middle ages in fact! Culturally they are much closer as well. (Male, English, Queen's Park Rangers FC, aged 24)

59: I always consider myself British. We're so much stronger as one than as four, and I'm proud of what we've achieved as a country. I imagine I'd have come in common with the average Glaswegian than the average Londoner, so find it hard to see us as totally separate countries. Talk of separation is madness given the likely future economic climate of the world. (Male, English, Everton FC, aged 25)

19: I think it depends where you come from. Certain areas of England are going to have more in common with Scotland/Wales than others do. (Male, English, Arsenal FC, aged 21)

59: The 4 countries have always enjoyed a sporting rivalry, and I'd like to see that continue. Although I consider myself British I'd always support, for example, an English boxer over a Scotsman, just as I'd support a Scouse boxer over a Yorkshireman. (Male, English, Everton FC, aged 25) 
It became clear that often English fans had made assumptions regarding the strength of feelings of division between England and Scotland outside of sport.

7: I don't quite get why so many Scots get all anti-British and want out of the union. I mean the whole excessive patriotism seems a little outdated to me, it's like people are stuck in the past for some reason or other. The world's a small place now and I mean I can't think of a good reason, even political, that would make the Scots hate the UK enough to want to leave and harbour such resentment towards the English. (Male, English, Manchester United FC, aged 31)

The Scottish fan in the sample responded to these kinds of comments by stressing that in his view the majority of Scottish people have no problem with the union between the two nations and that English fans views of Scottish anti-Englishness were largely unfounded.

46: I don't hate the UK I just consider myself to be Scottish and not British, why should Scotland not be independent? There are much smaller countries in Europe than us that are. Also I am sure this has been debated before but wanting out of the Union has nothing to do with hating the English, the majority of Scots have no problem with the English, myself included. I only dislike the English national team at any sport and would like to see them lose. This has nothing to do with the English people, however many would still like independence, it's hardly likely that if independence happened the SNP would erect Hadrian's Wall to stop those pesky Englanders crossing the border. 
In summary, whilst some English fans were antagonistic towards Scottish people and demonstrated a familiar 'little Englander' mentality, ${ }^{22}$ others were much more ambivalent. Moreover, there were also other English fans who were keen to stress unity between the two nations (England and Scotland) and felt that the rivalry did not extend beyond sport. Finally, whilst admittedly not representative of the views of all Scottish fans, there were some interesting insights provided by one Scottish fan that came out of debates with English fans which also downplayed feelings of animosity from the perspective of Scottish fans. This latter point was echoed in the findings of the interviews with Scottish fans to which we now turn.

\section{Interviews with Scottish fans}

The interviews with Scottish fans in the second study revealed that the rivalry between Scotland and England was frequently framed as a contest between Scottish underdogs and the dominant English. This narrative was argued to manifest itself in both a sporting and wider social context, echoing the arguments of Blain and Boyle: ${ }^{23}$

We're, whether rightly or wrongly, perceived to have limited resources, y'know, it's a little sort of David against Goliath kind of thing, y'know. So I'm rooting them on because they're the underdogs. (Richard)

You have this group mentality of... I think you have this feeling of Scotland's always the underdog, and you always want the underdog to do well, don't you? And England's always got so much more money, and so many better teams. And they have players here and there, and you don't want them to win, like. (Morag) 
And like everything that we learned was to do with battles. It was a lot to do with like Scotland overcoming England, which I feel like it affects a lot of people and how they view sport and that sort of thing, because it was always like the underdogs against big, bad England... like all of the sort of like battles that were like hundreds and hundreds of years ago. Like, people still bring that up, y'know, the invasions and all that sort of stuff. People sort of feel like they have to defend Scotland, and like England need to go down, and that sort of feeling still exists I think. (Michelle)

The comments from Michelle highlight that the rivalry between Scotland and England in sport is symbolically linked to the wider historical and political relationships between the two nations, highlighting the prevalence of the nationalist flagging of this rivalry within the Scottish education system and Scottish media, thus aligning with the contentions of Billig's 'banal nationalism' thesis. ${ }^{24}$ Furthermore, the routine flagging of this asymmetric relationship in the media was also argued to have been explicitly exploited for political purposes by Scottish nationalist politicians:

I think every time I hear Alex Salmond on TV, there's an undercurrent that we're being stifled as a... as a... as a nation, we're under some kind of thumb. And I probably... and I probably don't watch as much Scottish political coverage as I could, but I do feel that. I think that's the kind of sense of that which comes from Holyrood. The fact that the SNP did so well recently is testament to that, that people feel in Scotland that there's kind of no representation in England. And I think that comes across in the Scottish media quite... pretty, pretty clearly. (Michael) 
This 'underdog' narrative of the Scotland-England rivalry in soccer, sport and politics can also be linked to the aforementioned concerns regarding the existence of anti-English sentiment in Scottish society. Whilst many analyses of Scottish nationalism have argued that it tends to portray an inclusive form of 'civic nationalism' within media and political discourse, ${ }^{25}$ the existence of anti-English feeling represents one element of Scottish national identity which at least partially undermine such claims. For our interviewees, there was a widespread acceptance that anti-English feelings are evident in the domain of sport, with a range of contrasting explanations provided for this phenomenon:

...the relationship with England is part of what defines being Scottish, especially if you live down here. And there's a huge sense of... I just don't want to lose to England. It's not so much the winning, it's just not wanting to lose. And it's the same when they play someone else. I don't actually want them to lose. I just don't want them to win. (Scott)

For some reason, you seem to support the other team... (laughs)... when England are playing! (Mark)

I kind of try to formalise a bit, which is if England have a friendly, I want them to lose. Absolutely, I never want them to win a friendly, because I'm not harming England, it's just funny. I love it when they lose to small teams... but in tournaments, my rule of thumb is that I support them providing they play well. (Bert) 
Soccer was deemed to be the sport in which the rivalry between Scotland and England was most frequently extended to the 'Anyone But England' mantra of supporting England's opposition. Whilst this phenomenon was also argued to be evident in sports such as rugby union and cricket, it was argued that support for England's opposition was less common or vociferous in comparison to football, attributed to the contrasting social classes associated with the respective sports.

Again, the media were argued to play a central role in both causing this anti-English sentiment and the continued perpetuation of the rivalry between Scotland and England in soccer. In terms of the explanations offered as to why the media caused such ill-feeling, the annoyance expressed by Scots regarding the nature of sports broadcasters and commentators was particularly identified, with a commonly mooted argument that the hyperbolic comments regarding the quality of English teams at major sports events a source of frustration:

I don't have any nationalistic dislike of the English, at a kind of... a gross level. But it's the punditry and the media portrayal... it's like the media know if they put England on a pedestal, it's going to annoy the rest of the world who's not an England fan, and it's almost a kind of... it's like a red rag to a bull, I think to try and incite some kind of antipathy towards them. (Michael)

I might listen in and think the commentator is being biased towards England. And I guess that I've occasionally thought that in football and in rugby. And if you listen to the Scottish commentary you won't get the same, but that just might be me being blinkered! (Sandra) 
...mainly, it's just their arrogance, I suppose. But I guess with football, they think they've got the best football team in the world, whereas with the rugby they know that's not the case. So you're sort of less wanting them to win, so to be put in their place, if you like. (Mark)

However, the rationale for the expression of anti-English sentiment by Scots in sport was also attributed to the sporting failures of Scotland themselves, moving away from the external attributions offered above. Indeed, for many interviewees, the fact that Scotland have failed to qualify for a major international football tournament such as the FIFA World Cup or the UEFA European Championships since 1998 has precluded the opportunity to support their own nation at these events; this therefore was argued to lead Scots to support England's opponents to give an added level of enjoyment, excitement and humour to proceedings:

Well if it's a bit of banter and... y'know... as long as it doesn't turn in to a full-on fight or anything like that, then what's wrong with a bit of banter, y'know a bit of a laugh? As long as you're no winding someone up the wrong way. (Brian)

Another interesting argument related to this point is the proposition that Scots even play up to the stereotypes of Scots being anti-English in sport, echoing the arguments of Blain and Boyle and Giulianotti. ${ }^{26}$ It was argued that to a certain extent, Scots can tend to perform the role expected of them by others in relation to the expression of anti-English sentiment, both consciously and subconsciously:

I think from the Scottish point of view, a lot of it is this performativity. I think it is performing as anti-English. I think it quite amuses us. And it's partly because of 
the failings of our own national representatives... because I don't remember in the 1960 's... late '50s, '60s... I don't remember having this or people having this antiEnglish thing in football. (Bob)

These comments regarding the performed nature of anti-English sentiment by Scottish soccer supporters link nicely to a related point regarding the behaviour of the 'Tartan Army'. For many of the interviewees, the rivalry between Scotland and England was influenced by the attempts of Scots to deliberately distinguish themselves from the English, arguing that Scottish national identity was equally shaped by non-Englishness in addition to anti-Englishness:

...it's not about proving that you're the best any more, and so I think that Scotland fans go to games now with a different attitude than they used to, and to the way that England fans do. England fans go there thinking they are the best in the world, and wanting to prove that they're the best in the world. (Scott)

I think people probably are just against the whole English identity as well. I think people who don't know English people, and probably just have this image about being pretentious and nothing like... nothing like Scottish people and that sort of thing. So they probably use that sort of thing to distance themselves from England, and make it seem like they're totally different. (Michelle)

These comments therefore provide support for Bairner's contention ${ }^{27}$ that soccer provides an opportunity to distinguish Scottish supporters from their English rivals, thus avoiding the conflation of Scotland and Scottish identity with wider perceptions of the Englishness and Britishness. 
However, despite the clear consensus amongst our Scottish representatives that the rivalry with England remains salient for Scottish soccer fans, the lack of reciprocation from English fans regarding the importance of this rivalry was also acknowledged. Whilst England represents the 'significant other' for Scots in soccer and other international sports, it is clear that England's main rivals varies depending upon the sport in question, instead concentrating their fans attention on Germany and Argentina in football, Australia in cricket, and France in rugby union:

I used to say to these people "English people don't hate us", and they were like "they do, they do, there's like a big wall... they hate us and we hate them". And I was just like, "they don't, they don't give a fuck". They're too busy hating the French and the Germans, we're just like little Scotland to them. And... and who wants to admit that? That you're insignificant, your 5 million to their 55. (Bert)

The unrequited nature of the rivalry between Scotland and England is therefore a disappointment for Scottish fans, with the lack of reciprocation often viewed as a slightly patronising approach. It can therefore be argued that the gradual decline in the importance of this rivalry somewhat mirrors the declining success of the Scottish international team, thus encouraging the English to look elsewhere for more competitive rivals in soccer.

\section{Conclusion}

In this essay we have sought to test common media representations emphasising division between England and Scotland in soccer against the opinions of English and Scottish soccer fans themselves. The complexity of English views towards Scottish people both inside and 
outside of soccer was explored with English fans using examples from an online participant observation study; furthermore, views regarding anti-English sentiment as an element of Scottish national identity were explored using examples from semi-structured interviews with Scottish soccer fans. Findings revealed that whilst some English fans were antagonistic towards Scottish people and demonstrated a familiar 'little Englander' mentality, ${ }^{28}$ others were much more ambivalent. Moreover, there were also other English fans who were keen to stress unity between the two nations (England and Scotland) and felt that the rivalry did not extend beyond what happens in sport, particularly soccer. Finally, interesting insights were provided by one Scottish fan that came out of debates with English fans which also downplayed feelings of animosity from the perspective of Scottish fans.

Contrasting reflections on the nature of the rivalry between the two nations were equally evident within the responses of the other Scottish fans who participated in the semi-structured interviews. For some, anti-English sentiment was deemed to be a continuing element of Scottish national identity in soccer, with certain interviewees contending this sentiment at times became apparent outside of the domain of soccer and sport more broadly. However, the vast majority of participants denounced the simplistic conflation of this sporting rivalry with other political or societal, countering the common narratives of media representations of the relationship between the respective nations in soccer. Indeed, many of the interviewees emphasised that the cultural and societal similarities between the two nations are often ignored in such media representations. Nonetheless, it is important to note that these interviews were conducted prior to the Scottish independence referendum of September 2014; thus, it is only possible to speculate about the long-term impact of this political and constitutional wrangling on current perceptions of the rivalry between Scotland and England. 
Overall this essay has revealed that whilst representations of the England-Scotland soccer rivalry depicted in the media have clearly reinforced the opinions of many English fans regarding broader divisions (outside sport) between these neighbouring nations, most of the evidence from the two studies suggests that this is at odds with the views of the Scottish fans as well as a large proportion of the English fans under from the samples. We conclude that so long as the media perpetuate the social myth of division between the two nations in a simplistic manner the reality of the complex and evolving relationship between Scottish and English fans will remain unclear and misunderstood. We call for further studies into the England-Scotland soccer rivalry to understand whether feelings of division between the two sets of fans have been impacted by the 2014 Scottish referendum on independence and the 2016 'Brexit' from the European Union. 


\section{Notes}

${ }^{1}$ Bairner, "Football and the Idea of Scotland"; Bairner, Sport, Nationalism and Globalization; Blain and Boyle, "Battling Along the Boundaries"; Giulianotti, "Scotland's Tartan Army in Italy"; Giulianotti, "Football and the Politics of Carnival"; Jarvie and Walker, "Ninety minute patriots?"; Kelly, Flowers of Scotland?; Kowalski, "Cry for Us, Argentina"; Moorhouse, "Scotland Against England"; Moorhouse, "One State, Several Countries".

${ }^{2}$ Bairner, "Football and the Idea of Scotland"; Duke and Crolley, Football, Nationality, and the State; Jarvie and Walker, "Ninety minute patriots?"; McCrone, Understanding Scotland; Moorhouse, "One State, Several Countries".

3. Bairner, "Football and the Idea of Scotland"; Moorhouse, One State, Several Countries; Whigham, "Anyone But England?"”.

4. McIntosh, Sim and Robertson, “We Hate the English'”; McIntosh, Sim and Robertson, "'It's As If You're Some Alien"'; Miller, "Introduction: From last empress to First Minister".

5. Miller, "Introduction: From last empress to First Minister"; Whigham, "Sending 'Proud Edward's Army"”.

11. Gibbons, "Contrasting representations of Englishness during FIFA World Cup Finals."

7. Bairner, "Football and the Idea of Scotland"; Blain and Boyle, "Battling Along the Boundaries"; Bradley, "The Patriot Game"; Giulianotti, "Scotland's Tartan Army in Italy".

8. Bairner, "Football and the Idea of Scotland".

9. Blain and Boyle, "Battling Along the Boundaries"; Giulianotti, "Scotland's Tartan Army in Italy".

10. Bairner, "Football and the Idea of Scotland"; Bairner, Sport, Nationalism and Globalization.

11. Carrington, "Too Many St. George's Crosses"; Gibbons, English National Identity and Football Fan Culture; Malcolm, "Malign or Benign?"; Parry and Malcolm, "England's Barmy Army"; Perryman, Ingerland; Vincent et al., "England Expects".

12. Whigham, "Sending "Proud Edward's Army".

13. Hussain and Miller, "The Auld Enemy in the new Scotland"; Hussain and Miller, "Towards a Multicultural Nationalism?"; McIntosh, Sim and Robertson, "We Hate the English"”; Watson, Being English in Scotland; Whigham, "“Anyone But England?".

14. Bairner, "Football and the Idea of Scotland"; Whigham, "“Anyone But England?"”.

15. Moorhouse, "Professional Football and Working Class Culture"; Moorhouse, "Repressed Nationalism and Professional Football"; Moorhouse, "Scotland Against England"; Moorhouse, "From Zines Like These?"; Moorhouse, "One State, Several Countries".

16. Moorhouse, "Repressed Nationalism and Professional Football"; Moorhouse, "Scotland Against England".

17. Bairner, Sport, Nationalism and Globalization; BBC News, "Police Fears Over 'Anyone But England' Tshirt"; Blain and Boyle, "Battling Along the Boundaries"; Collins, "Exploring the Anyone But England Phenomenon"; Dickie, "Scots Refuse to Kick"; Hassan, “To Be Scottish"; Kelly, "What's Behind Anyone But England?"; Watson, Being English in Scotland.

${ }^{18}$ For instance, the BBC termed the fixture 'a fierce football rivalry' in an article published prior to the 2000

European Football Championships- BBC News, 1999

http://news.bbc.co.uk/1/hi/special_report/1999/11/99/battle_of britain/473756.stm

${ }^{19}$ Elias, What is Sociology, 50.

${ }^{20}$ The term 'thread' refers to a discussion thread in which topics are discussed by forum members by way of them 'posting' their responses.

${ }^{21}$ Russell, Looking North: Northern England and the national imagination.

${ }^{22}$ Gibbons, Dixon and Braye, “The GB Football Team for London 2012: What's all the fuss about?”; Maguire,

"Globalization, Sport and National Identities".

23. Blain and Boyle, "Battling Along the Boundaries".

24. Billig, Banal Nationalism.

25. Leith and Soule, Political Discourse and National Identity in Scotland; Mycock, "SNP, Identity, and Citizenship".

26. Blain and Boyle, "Battling Along the Boundaries"; Giulianotti, "Scotland's Tartan Army in Italy".

27. See note 7 .

${ }^{28}$ Gibbons, Dixon and Braye, “The GB Football Team for London 2012: What's all the fuss about?"; Maguire, "Globalization, Sport and National Identities". 


\section{References}

Bairner, Alan. "Football and the Idea of Scotland". In Scottish Sport in the Making of the Nation: Ninety Minute Patriots?, edited by Grant Jarvie and Graham Walker, 9-26. Leicester: Leicester University Press, 1994.

Bairner, Alan. Sport, Nationalism and Globalization: European and North American Perspectives. Albany, NY: State University of New York Press, 2001.

BBC News. 2010. "Police Fears Over 'Anyone But England' T-shirt”. BBC News Online, February 24. http://news.bbc.co.uk/1/hi/scotland/north_east/8533791.stm

Billig, Michael. Banal Nationalism. London: Sage, 1995.

Blain, Neil, and Raymond Boyle. "Battling Along the Boundaries: The Marking of Scottish Identity in Sports Journalism”. In Scottish Sport in the Making of the Nation: Ninety Minute Patriots?, edited by Grant Jarvie and Graham Walker, 125-141. Leicester: Leicester University Press, 1994.

Bradley, Joseph. “The Patriot Game: Football's Famous 'Tartan Army'.” International Review for the Sociology of Sport 37, no. 2 (2002): 177-197. doi: 10.1177/1012690202037002004.

Carrington, Ben. “Too Many St. George's Crosses to Bear”. In The Ingerland Factor: Home Truths from Football, edited by Mark Perryman, 71-86. Edinburgh, Mainstream Publishing, 1999. 
Collins, Nick. 2010. "Exploring the Anyone But England Phenomenon”. Telegraph Online, June 12. http://www.telegraph.co.uk/sport/football/competitions/world-cup2010/7822857/ Exploring-the-Anyone-But-England-phenomenon.html

Dickie, Mure. 2014. "Scots Refuse to Kick Into Touch 'Anyone But England' Mentality". Financial Times Online, June 15. http://www.ft.com/cms/s/2/335a781a-f4a1-11e3-a14300144feabdc0.html\#axzz4HEdvSwnJ

Duke, Vic, and Linda Crolley. Football, Nationality, and the State. Harlow: Longman, 1996.

Elias, Norbert. What is Sociology? London: Hutchinson, 1978.

Gibbons, Tom. "Contrasting Representations of Englishness During FIFA World Cup Finals”. Sport in History 30, no. 3 (2010): 422-446. doi: 10.1080/17460263.2010.505408.

Gibbons, Tom. English National Identity and Football Fan Culture: Who Are Ya?. Farnham, Ashgate, 2014.

Gibbons, Tom, Kevin Dixon and Stuart Braye. "The GB Football Team for London 2012: What's All The Fuss About?" In The Impact of the 2012 Olympic \& Paralympic Games: Diminishing Contrasts, Increasing Varieties, edited by Kevin Dixon and Tom Gibbons, 35-55. Basingstoke: Palgrave, 2015. 
Giulianotti, Richard. "Scotland's Tartan Army in Italy: The Case for the Carnivalesque". Sociological Review 39, no. 3 (1991): 503-527. doi: 10.1111/j.1467-954X.1991.tb00865.x.

Giulianotti, Richard. "Football and the Politics of Carnival: An Ethnographic Study of Scottish Fans in Sweden." International Review for the Sociology of Sport 30, no. 2 (1995): 191-219. doi: $10.1177 / 101269029503000205$.

Hassan, Gerry. 2010. "To Be Scottish Should Not Be About Being Anti-English". Guardian Online, June 23. http://www.guardian.co.uk/commentisfree/2010/jun/23/anyone-but-englandscottish

Hussain, Asifa, and William Miller. "The Auld Enemy in the New Scotland". In AngloScottish Relations From 1900 to Devolution and Beyond, edited by William Miller, 183-202. Oxford: Oxford University Press, 2005.

Hussain, Asifa, and William Miller. Towards a Multicultural Nationalism? Anglophobia and Islamophobia in Scotland. Devolution Briefings: Briefing No. 24. Economic \& Social Research Council, 2005.

Jarvie, Grant, and Graham Walker. "Ninety Minute Patriots? Scottish Sport in the Making of the Nation". In Scottish Sport in the Making of the Nation: Ninety Minute Patriots?, edited by Grant Jarvie and Graham Walker, 9-26. Leicester: Leicester University Press, 1994.

Kelly, John. "Flowers of Scotland? A Sociological Analysis of National Identities: Rugby Union and Association Football in Scotland”, PhD diss., Loughborough University, 2007. 
Kelly, Jon. 2010. "What's Behind Anyone But England?". BBC News Online, June 14. http://news.bbc.co.uk/1/hi/8733373.stm

Kowalski, Ronnie. “'Cry for Us, Argentina': Sport and National Identity in Late Twentiethcentury Scotland”. In Sport and National Identity in the Post-war World, edited by Adrian Smith and Dilwyn Porter, 69-87. London: Routledge, 2004.

Leith, Murray Stewart, and Daniel Soule. Political Discourse and National Identity in Scotland. Edinburgh, Edinburgh University Press, 2011.

Maguire, Joseph. "Globalization, Sport and National Identities." Sport in Society 14, no. 7/8 (2011): 978-993.

Malcolm, Dominic. "Malign or Benign? English National Identities in Cricket." Sport in Society 12, no. 4/5 (2009): 613-628. doi: 10.1080/17430430802702897.

McCrone, David. Understanding Scotland: The Sociology of a Stateless Nation. London: Routledge, 1992.

McIntosh, Ian, Duncan Sim, and Douglas Robertson. "We Hate the English, Except For You, Cos You're Our Pal': Identification of the 'English' in Scotland.” Sociology 38, no. 1 (2004): 43-59. doi: 10.1177/0038038504039360. 
McIntosh, Ian, Duncan Sim, and Douglas Robertson. “'It's As If You're Some Alien': Exploring Anti-English Attitudes in Scotland” Sociological Research Online 9, no. 2 (2004). http://www.socresonline.org.uk/9/2/mcintosh.html.

Miller, William. "Introduction: From Last Empress to First Minister". In Anglo-Scottish Relations From 1900 to Devolution and Beyond, edited by William Miller, 1-16. Oxford: Oxford University Press, 2005.

Moorhouse, Bert. "Professional Football and Working Class Culture: English Theories and Scottish Evidence." Sociological Review, 32 (1984): 285-315. doi: 10.1111/j.1467954X.1984.tb00815.x.

Moorhouse, Bert. "Repressed Nationalism and Professional Football: Scotland Versus England”. In Sport, Culture, Society: International Historical and Sociological Perspectives, edited by James A. Mangan and Roy Small, 52-59. London: Spon, 1985.

Moorhouse, Bert. "Scotland Against England: Football and Popular Culture." International Journal of the History of Sport 4, no. 2 (1987): 189-202. doi: 10.1080/09523368708713625.

Moorhouse, Bert. "From Zines Like These? Fanzines, Tradition and Identity in Scottish Football”. In Scottish Sport in the Making of the Nation: Ninety Minute Patriots?, edited by Grant Jarvie and Graham Walker, 173-194. Leicester: Leicester University Press, 1994. 
Moorhouse, Bert. "One State, Several Countries: Soccer and Nationality in a 'United' Kingdom.” International Journal of the History of Sport 12, no. 2 (1985): 55-74. doi: $10.1080 / 09523369508713895$.

Mycock, Andrew. "SNP, Identity, and Citizenship: Re-imagining State and Nation." National Identities 14, no. 1 (2012): 53-69. doi: 10.1080/14608944.2012.657078.

Parry, Matthew and Dominic Malcolm. "England's Barmy Army: Commercialisation, Masculinity and Nationalism.” International Review for the Sociology of Sport 39, no. 1 (2004): 75-94. doi: 10.1177/1012690204040524.

Perryman, Mark. Ingerland: Travels with a Football Nation. London, Simon and Schuster, 2006.

Russell, Dave. Looking North: Northern England and the National Imagination. Manchester, Manchester University Press, 2004.

Vincent, John, Edward Kian, Paul Pedersen, Aaron Kuntz, and John Hill. "England Expects: English Newspapers' Narratives About the English Football Team in the 2006 World Cup." International Review for the Sociology of Sport 45, no. 2 (2010): 199-223. doi: $10.1177 / 1012690209360084$

Watson, Murray. Being English in Scotland. Edinburgh: Edinburgh University Press, 2003. 
Whigham, Stuart. “'Anyone But England'? Exploring Anti-English Sentiment as Part of Scottish National Identity in Sport." International Review for the Sociology of Sport 49, no. 2 (2014): 152-174. doi: 10.1177/1012690212454359.

Whigham, Stuart. “Sending 'Proud Edward's Army Tae Think Again': A Scottish Perspective on the Quest for an English Identity in Sport". In Sport and English National Identity in a 'Disunited Kingdom', edited by Tom Gibbons and Dominic Malcolm. London: Routledge, in press. 